\title{
Semipersistent Whitefly Transmission of Squash vein yellowing virus, Causal Agent of Viral Watermelon Vine Decline
}

Susan E. Webb, University of Florida, Entomology and Nematology Department, Gainesville, FL 32611; Scott Adkins, United States Department of Agriculture-Agricultural Research Service (USDA-ARS), Fort Pierce, FL 34945; and Stuart R. Reitz, USDA-ARS, Tallahassee, FL 32308

\begin{abstract}
Webb, S. E., Adkins, S., and Reitz, S. R. 2012. Semipersistent whitefly transmission of Squash vein yellowing virus, causal agent of viral watermelon vine decline. Plant Dis. 96:839-844.

Squash vein yellowing virus (SqVYV), a recently described Ipomovirus sp. in the family Potyviridae, is the cause of viral watermelon vine decline, a devastating disease in Florida. SqVYV is known to be transmitted by the whitefly, Bemisia tabaci (Gennadius) B strain, but details of the transmission process have not previously been investigated. We completed a series of experiments to determine efficiency of transmission, effects of different acquisition and inoculation access periods, the length of time that whiteflies retained transmissible virus, and the minimum time needed to complete a cycle of acquisition and inocula-

tion. Efficiency was low, with at least 30 whiteflies per plant needed for consistent transmission. Acquisition leading to later transmission peaked at $4 \mathrm{~h}$, and inoculation access periods longer than 4 to $8 \mathrm{~h}$ led to no increase in infection rates. Whiteflies retained virus only a short time, with no transmission by $24 \mathrm{~h}$ after removal from infected plants. A minimum of $3 \mathrm{~h}$ was needed to complete a cycle of transmission under laboratory conditions. These results demonstrate semipersistent transmission of SqVYV and will help refine models of the epidemiology of this virus and the disease it causes.
\end{abstract}

Bemisia tabaci (Gennadius), biotype $\mathrm{B}$, has caused problems for vegetable growers in Florida since at least 1987 (26,30), first, because the feeding of nymphs induces various physiological disorders such as squash silverleaf (30) and tomato irregular ripening (26) and, second, because of the ability of adults to vector plant viruses (7). Since the introduction of the B biotype, several whitefly-transmitted viruses have been found in Florida vegetables, including Tomato yellow leaf curl virus (23) and Bean golden mosaic virus (5), both in the family Geminiviridae. The Crinivirus sp. Tomato chlorosis virus has also been reported (29). However, until 2003, no whitefly-transmitted viruses had been found in cucurbit vegetables in Florida. Now, growers face the challenge of managing three such viruses, which have appeared in rapid succession: Squash vein yellowing virus (SqVYV) (1), Cucurbit leaf crumple virus (4), and Cucurbit yellow stunting disorder virus (22). Of these, SqVYV appears to be the most economically damaging $(1,11)$.

SqVYV is a whitefly-transmitted virus in the family Potyviridae, genus Ipomovirus. It is mechanically transmissible and was first isolated from yellow summer squash (Cucurbita pepo L.) collected in west-central Florida in 2003 (1). It was subsequently demonstrated to be the causal agent of watermelon vine decline, a devastating disease of watermelon (Citrullus lanatus (Thunb.) Matsum. \& Nakai) responsible for major losses since early $2003(1,11,25)$. Infected watermelon plants, often close to harvest, collapse as leaves and stems develop necrotic areas that spread, leading to death of the plant. An interior rind necrosis and an off-flavor often make the fruit unmarketable. SqVYV is most closely related to

\section{Corresponding author: S. E. Webb, E-mail: sewe@ufl.edu}

Mention of a trademark, warranty, proprietary product or vendor does not constitute a guarantee by the United States Department of Agriculture and does not imply its approval to the exclusion of other products or vendors that may also be suitable.

Accepted for publication 22 December 2011.

http://dx.doi.org/10.1094/PDIS-09-11-0761

(C) 2012 The American Phytopathological Society
Cucumber vein yellowing virus (CVYV) $(1,17)$. Both CVYV and another closely related Ipomovirus sp., Cassava brown streak virus (CBSV), appear to be transmitted in a semipersistent manner $(10,18,19)$.

Semipersistent transmission is a form of noncirculative transmission (9). It differs from nonpersistent transmission in the length of time an insect vector takes to acquire and transmit virus, and in the length of time the vector retains the virus. Although nonpersistently transmitted viruses can be rapidly acquired from epidermal and mesophyll cells during short test probes that a vector may use to determine host suitability, semipersistently transmitted viruses are generally acquired from and transmitted to phloem cells (20,21). Feeding in the phloem takes place after an insect accepts the plant as a suitable host; reaching the phloem takes much longer (15 to $30 \mathrm{~min}$ ) than probing the epidermis (9). Unlike in circulative transmission, where there is a latent period after acquisition, there is none in semipersistent transmission. This suggests that virus particles are bound to the stylets (28) or areas of the foregut (e.g., antecibarium and postcibarium; (8) rather than passing through the gut and entering salivary glands as in circulative transmission. Further, in circulative transmission, insects remain viruliferous for days, weeks, or even months (in the case of viruses that multiply in their vector) whereas, in semipersistent transmission, insects retain virus for hours to days (20). Semipersistent transmission has been demonstrated in a number of virus genera and insect vector families. For example, whitefly-vectored viruses in the genera Crinivirus and Ipomovirus have been shown to be transmitted in a semipersistent manner $(10,21)$.

Our preliminary experiments showed that $B$. tabaci could act as a vector of SqVYV (1), moving the virus from infected squash to squash and watermelon and from an infected cucurbitaceous weed, Momordica charantia L., to watermelon and squash (2). These earlier experiments involved mass exposure of infected source plants to whiteflies, with subsequent replacement of the source plants with noninfected target plants. In this study, we characterize basic parameters of transmission of SqVYV by B. tabaci under more controlled conditions to demonstrate its semipersistent mode of transmission. Characterizing the specific parameters of transmission of SqVYV is also a critical step in the process of developing a systems approach to managing watermelon vine decline (27). 


\section{Materials and Methods}

Whitefly colony. The B. tabaci colony used in this study was maintained on cotton (Gossypium hirsutum L.) and collard (Brassica oleracea L. var. acephala DC) (6), neither of which is susceptible to SqVYV (1; S. E. Webb, unpublished data). For all experiments, a cohort of insects developing from oviposition over a 24-h period was used to reduce potential variation in transmission due to whitefly age. Adult whiteflies were 4 to 7 days old at the time of the experiments. No attempt was made to balance the sex ratio of insects used in experiments.

Plants. 'Sunray' squash, a yellow straightneck summer squash (Cucurbita pepo L.; Seminis, St. Louis), was used in all experiments. Plants were grown in $15.2-\mathrm{cm}$ plastic azalea pots using Metro-Mix Ag Lite Mix (Sun Gro Horticulture, Belleview, WA) and pasteurized sand (Quikrete, Atlanta), 3:1, vol/vol, or Metromix 200 without added sand. Plants serving as target plants were used when they had at least one but not more than three expanded true leaves. Noninfected squash plants were grown as negative controls or sentinel plants in the same greenhouse as the exposed target plants and were also placed among the target plants during inoculation access. None of these plants developed symptoms in any of the experiments reported here. All plants were numbered at seeding, and the numbers were used to randomly assign plants (including those used as sentinels) to treatments using Proc Plan (SAS, version 9.2; SAS Institute, Cary, NC).

Virus source. SqVYV (derived from the originally collected isolate) was maintained in Sunray squash by mechanical inoculation and whitefly transmission. Mechanical inoculation was on a weekly basis, using $0.02 \mathrm{M}$ potassium phosphate buffer, $\mathrm{pH} 7.4$, with the addition of corundum as an abrasive $(100 \mathrm{mg} / \mathrm{ml})$. Every 4 to 6 weeks, whiteflies were used to transfer the virus. The inoculum source for experiments came from plants that had been mechanically inoculated 10 to 14 days earlier from a source that had been transmitted by whiteflies within the previous 4 to 6 weeks. Unlike the aphid-transmitted Potyvirus spp., transmissibility of SqVYV by whiteflies appears to be unaffected by multiple passages via mechanical inoculation (S. E. Webb, unpublished data).
Virus acquisition. Whiteflies were exposed to infected plants for virus acquisition within a large cage $(91.4$ by 71.1 by $61 \mathrm{~cm})$ consisting of a wooden frame screened with cotton organdy (Silk Road Textile Merchants, Austin, TX). The Plexiglas top of the cage was $61 \mathrm{~cm}$ high at the rear of the cage and $45.7 \mathrm{~cm}$ in front to make it easier to see plants and whiteflies. Adults were collected with a gentle vacuum, using a Gast vacuum pump (model DOAP704-AA; Fisher Scientific, Pittsburgh), at the lowest possible setting. A 1.0-by-0.5-mm hole was cut near the end of a $170-\mathrm{cm}$ length of plastic tubing (Tygon; Fisher Scientific) leading from the vacuum port to the glass collecting tube to reduce pressure to a level where it was just possible to collect whiteflies. If whiteflies could not be easily dislodged, it was assumed that they were actively feeding and they were left alone to avoid injuring them. After collection, whiteflies were chilled for $2 \mathrm{~min}$ at 3 to $5^{\circ} \mathrm{C}$ and then tapped into clip cages for inoculation access.

Whole-plant cages versus clip cages. We compared wholeplant cages and clip cages to determine whether confining whiteflies to clip cages, where they would have to feed through mesh, for inoculation would interfere with transmission. The clip cages used in our experiments were screened on both top and bottom to prevent escape of whiteflies, with a mesh size that allowed whiteflies to feed and oviposit on the leaf through the mesh (Fig. 1A). The whole-plant cages were made of lightweight floating row cover (Gardens Alive, Lawrenceburg, IN) folded into a rectangle and the edges taped with 19-mm-wide strapping tape (3M, St Paul, MN), except for the lower edge, which fit over the pot holding the plant. The heavy tape provided support for the fabric, so that the cage did not rest on the plant. A rubber band was used to secure it (Fig. 1B). Source plants were 18 days post inoculation (dpi) and target plants had one to two true leaves. Whiteflies were given a 24-h acquisition access period (AAP) in the large cage described above. Whiteflies were then aspirated, also as described above, into glass tubes, chilled for $2 \mathrm{~min}$, and added (30 per cage) to either a whole-plant cage or a clip cage. Each cage type was replicated 25 times. Additional plants were used as negative controls in the greenhouse, and other plants were exposed to the large number of remaining whiteflies in the acquisition cage as positive controls. After a 24 -h inoculation access period (IAP), cages were

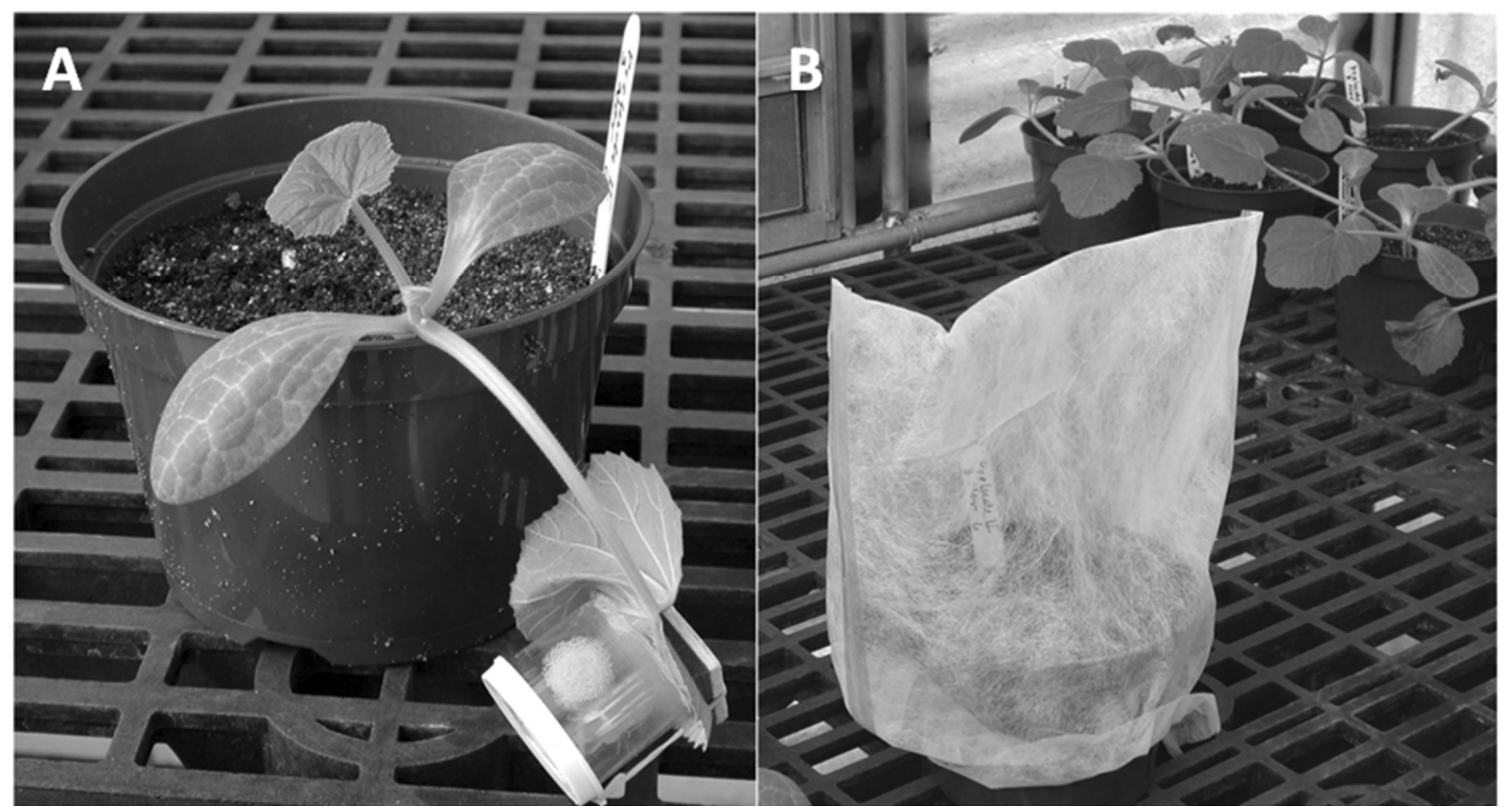

Fig. 1. Two cage types were tested for virus acquisition. A, First was a clip cage screened on both top and bottom with a mesh size that allowed whiteflies to feed and oviposit but not escape. Whiteflies were introduced through a hole in the side of the cage. It was compared with B, a whole-plant cage for effects on transmission and ease of use. 
removed, and plants were treated with insecticide after returning them to the greenhouse for symptom development. Plants were evaluated by visual inspection of symptoms beginning at 5 days after treatment and ending at 10 days. An arbitrarily selected sample of symptomatic and nonsymptomatic plants was tested by reverse-transcription polymerase chain reaction (RT-PCR) to confirm infection status with SqVYV (2). Because all symptomatic plants tested positive for SqVYV infection and all nonsymptomatic plants tested negative for SqVYV, we did not test plants from every replicate of every subsequent experiment but relied mainly on the distinctive symptoms of infection for evaluation.

Efficiency of transmission. To determine how efficiently the virus was transmitted, whiteflies were first given a 24-h AAP on infected squash plants (15 dpi). Then, approximately 30,15 , or 8 whiteflies were collected and placed in clip cages as described above. Whiteflies were assigned to treatments in such a way that all treatments had a similar range of AAPs ( 24 to $26 \mathrm{~h}$ ). Thirty plants were used for each whitefly density treatment. After a 24-h IAP, clip cages were removed. Plants were then returned to the greenhouse and treated with insecticide to kill any nymphs hatching from eggs deposited through the screening. Plants were evaluated 7 to 10 days later as described above. The experiment was replicated three times.

AAP. Infected squash plants were added to the rearing cage containing cotton plants from which adult whiteflies had begun emerging 6 to 7 days earlier. The cotton plants were cut off at the soil line and gently tapped and shaken to dislodge whiteflies, then removed from the cage so that whiteflies would settle on squash plants for acquisition. Whiteflies (30 per plant) were then collected at intervals following introduction of infected squash plants: 0.5 (minimum time required to collect 30 whiteflies), 1, 2, 4, 8, and 24 h. Whiteflies were given a 24-h IAP in clip cages on noninfected plants. Over the three experiments, source plants ranged from 11 to $15 \mathrm{dpi}$ and target plants ranged from 11 to 17 days old, with one to three true leaves, with the longer times in the winter when greenhouses were cooler. In the first replicate, 15 plants were used for each AAP, and the 0.5-h AAP was not tested. For the second and third replications of the experiment, 25 plants were used for each AAP. As before, plants were returned to the greenhouse for symptom development after removing clip cages and treatment with insecticide.

IAP. Whiteflies were given a 24-h AAP on infected squash and collected, as described above. Thirty whiteflies were placed in a clip cage on each of 25 plants tested per time period. Clip cages were removed from target plants at intervals ranging from $30 \mathrm{~min}$ to $4 \mathrm{~h}$ in the first replicate, from $30 \mathrm{~min}$ to $8 \mathrm{~h}$ in the second, and from $30 \mathrm{~min}$ to $24 \mathrm{~h}$ in the third. The virus source plants for all replications of the experiment were $14 \mathrm{dpi}$ and the target plants were 14 days old, with two true leaves. After the IAP, clip cages were removed and plants treated with insecticide after returning them to the greenhouse for symptom development. Plants were visually evaluated for symptoms 10 days later, as described above.

Retention time. Whiteflies were given a 4- or 24-h AAP on infected squash that had been mechanically inoculated 12 days earlier. We replaced the infected plants with noninfected plants after whiteflies for the 0 -h treatment had been collected and placed in clip cages ( 30 whiteflies per plant, 25 plants per treatment). The remaining whiteflies were then allowed to feed on the noninfected plants for $1,2,4,8$, or $24 \mathrm{~h}$ before collecting them to put into clip cages to place on the 2-week-old target plants for a 24-h IAP. After clip cages were removed, plants were returned to the greenhouse and treated with insecticide as described above. As before, plants were visually evaluated for symptom development 10 days later.

Minimum time to complete a cycle of transmission (AAP plus IAP). Using the results from earlier experiments, we tested all possible combinations of 1,2 , and $4 \mathrm{~h}$ for both AAP and IAP. Although we determined that whiteflies could acquire virus within 30 min, the time involved in collecting whiteflies for each AAP precluded the use of this short acquisition time. At each AAP, 30 whiteflies were placed in each of 30 clip cages and assigned to plants by IAP, with 10 plants for each of the three IAP times. AAPs, as in most of our experiments, were actually plus or minus $15 \mathrm{~min}$ (a total of $30 \mathrm{~min}$ to collect enough whiteflies for 30 clip cages). The virus source plants for both replicates were $17 \mathrm{dpi}$. The target plants had one to three true leaves. Positive controls were given a 4-h AAP and a 24-h IAP. At the end of the respective IAP, clip cages were removed, and plants were returned to the greenhouse and treated with insecticide as described above. Plants were visually evaluated for symptom development 10 days later.

Data analyses. In all experiments, plants were coded in a binary manner for virus transmission (i.e., each plant was scored as either positive or negative for virus infection). Because the dependent variable was a binary response and the independent variables of interest were quantitative (i.e., whitefly density or time interval), logistic models were fitted to determine how the frequency of virus transmission was related to the independent variables.

Sets of orthogonal contrasts were constructed to determine the form of relationships between transmission and the different levels of each independent variable. Analyses were conducted either with PROC GLIMMIX (efficiency of transmission, AAP, and IAP) or PROC LOGISTIC (retention time and minimum time for complete cycle of transmission) in SAS (version 9.2; SAS Institute). Pairwise comparisons of means among different levels of the quantitative independent variables for each experiment were made with the LSMEANS option.

\section{Results}

Whole-plant cages versus clip cages. When we compared the use of whole-plant cages with clip cages for inoculation, we found no differences in transmission. In all, 13 of 25 plants from the whole-plant cage treatment and 14 of 25 plants from the clip cage treatment developed symptoms of SqVYV infection. Whole-plant cages were harder to use because of the difficulty of removing them without allowing whiteflies to escape into the greenhouse. Confining them inside another larger cage (10) was not practical because of space constraints. Thus, clip cages were used for inoculation access in all subsequent experiments.

Efficiency of transmission. SqVYV was not very efficiently transmitted in this experiment. At least 30 whiteflies per cage were required before transmission rates reached a high of $57 \%$ with a 24-h AAP and a 24-h IAP. The mean transmission for the three replicates of the experiment was $42 \pm 6 \%$. With 15 whiteflies per cage, a mean of $22 \pm 5 \%$ of plants became infected. In the initial replicate of the experiment, there was no transmission when eight whiteflies per plant were used but, in the final two replicates, there was a mean of $15 \%$ transmission at this level (overall mean of $10 \pm$ $3 \%$ ). Although whiteflies did not transmit SqVYV very efficiently, the frequency of infected plants was significantly different among the three whitefly densities $(F=11.0$, df $=1,265, P<0.0001)$. There was a significant positive linear trend in the relationship between whitefly density and proportion of virus infected plants (linear contrast: $F=22.0$, df $=1,265, P<0.0001$; Fig. 2 ).

Acquisition access. The length of the AAP significantly affected the frequency of SqVYV infections of target squash plants $(F=$ 14.62, df $=5,367, P<0.0001)$. The incidence of infection was extremely low when whiteflies received only a 30-min AAP; however, the frequency of infection increased substantially when the AAP was increased to 1 to $2 \mathrm{~h}$ in duration. The frequency of infection again increased significantly when the AAP was increased to 4 to $8 \mathrm{~h}$. However, infection rates did not show a continuing increase with an AAP of $24 \mathrm{~h}$. In fact, the infection rate for that AAP declined from the observed rates at 4- and 8-h AAPs (Fig. 3). There was a significant linear increase in infection frequency over time (contrast: $F=12.30$, df $=1,367, P<0.0001$ ) but the linear increase was not consistent, as indicated by the significant quadratic $(F=$ $59.0, \mathrm{df}=1,367, P<0.0001)$ and cubic contrasts $(F=10.0, \mathrm{df}=$ $1,367, P=0.0012$ ).

Inoculation access. The length of the IAP significantly affected the frequency of SqVYV infections of target squash plants $(F=$ 6.77 , df $=5,367, P<0.0001)$. Infection rates tended to increase 
with increasing IAP (linear contrast: $F=19.2$, df $=1,367, P<$ 0.0001 ) but began to plateau at the longest IAP times (quadratic contrast: $F=20.0$, df $=1,367, P<0.0001)$. When whiteflies experienced a short IAP ( 0.5 to $1 \mathrm{~h}), \mathrm{SqVYV}$ infection rates were very low $(<6.5 \%)$. Infection frequencies did increase significantly up to an IAP of $8 \mathrm{~h}$, with the greatest rate of change occurring from a 1- to 2-h IAP. However, the frequency of infection did not continue to increase with a 24-h IAP, suggesting that the virus was not retained over longer time periods by whiteflies (Fig. 4). The level of variation between the experiments suggests differences in the availability of virus in the source plants.

Retention. In this experiment, plants exposed to whiteflies that experienced a 4-h AAP were infected at significantly higher rates than were plants exposed to whiteflies that had a 24-h AAP $\left(\chi^{2}=\right.$ 5.36 , $\mathrm{df}=1, P=0.02$ ). Regardless of the AAP duration, infection rates declined significantly with the length of time that whiteflies had been removed from infected source plants $\left(\chi^{2}=49.7, \mathrm{df}=5, P\right.$ $<0.0001)$. There were significant linear (contrast: $\chi^{2}=5.74, \mathrm{df}=$

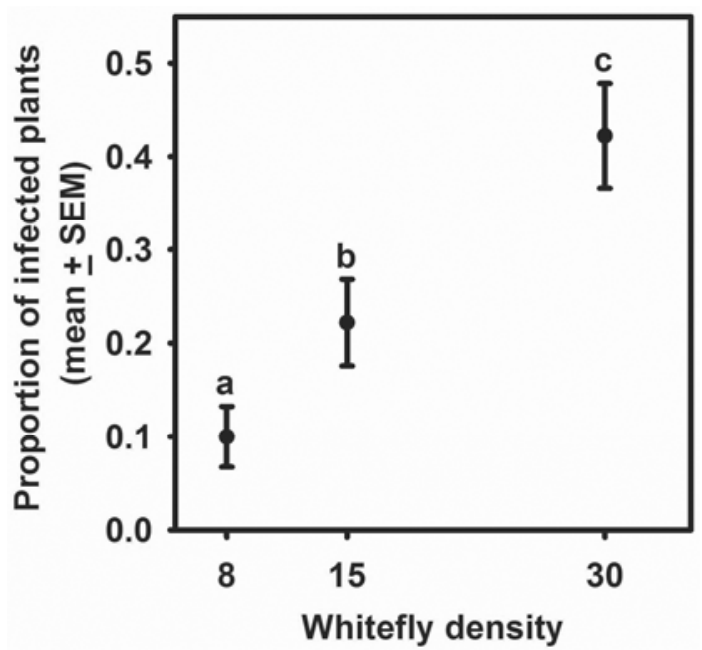

Fig. 2. Frequency of Squash vein yellowing virus (SqVYV) infection of 'Sunray' squash when exposed to different densities of Bemisia tabaci adults for $24 \mathrm{~h}$. B. tabaci adults had been given a 24-h acquisition access period to SqVYV-infected squash plants before exposure of target plants. Data are the mean proportion $( \pm$ standard error of the mean [SEM]) of target plants infected with SqVYV. Means with different letters are significantly different $(P<0.05)$.

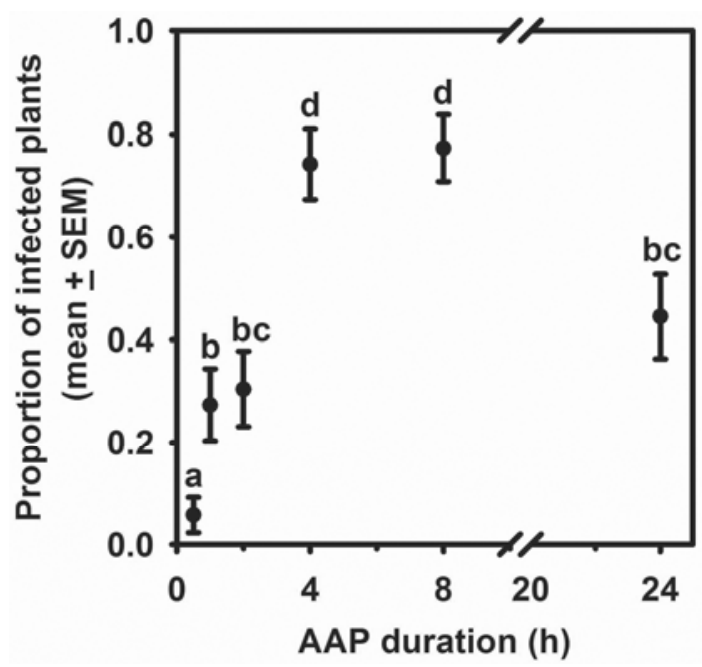

Fig. 3. Frequency of Squash vein yellowing virus (SqVYV) infection of 'Sunray' squash when exposed to cohorts of 30 Bemisia tabaci adults that had been given acquisition access periods (AAPs) of 0.5 to $24 \mathrm{~h}$. Target plants were exposed to $B$. tabaci adults for a 24-h inoculation access period. Data are the mean proportions ( \pm standard error of the mean [SEM]) of target plants infected with SqVYV. Means with different letters are significantly different $(P<0.05)$.
$1, P=0.016)$ and quadratic $\left(\chi^{2}=4.51, \mathrm{df}=1, P=0.033\right)$ components in this trend, indicating that virus retention declined rapidly, especially in the first hour after removal from source plants, and that whiteflies completely shed the virus within 8 to 24 $\mathrm{h}$ after removal from source plants (Fig. 5).

Minimum time to complete a cycle of transmission (AAP plus IAP). In this experiment, increasing the duration of the AAP and IAP for whiteflies led to greater infection rates of squash plants with SqVYV. There was no significant interaction between AAP and IAP $\left(\chi^{2}=0.58, \mathrm{df}=4, P=0.97\right)$ but each of these main effects had a significant effect on infection rates (main effect for AAP: $\chi^{2}=12.7, \mathrm{df}=2, P=0.0017$; main effect for IAP: $\chi^{2}=8.91$, df $=2, P=0.012$ ). The length of the AAP appeared to have a greater influence on infection occurring, because infection was detected for all levels of IAP with an AAP of $4 \mathrm{~h}$. However, if the

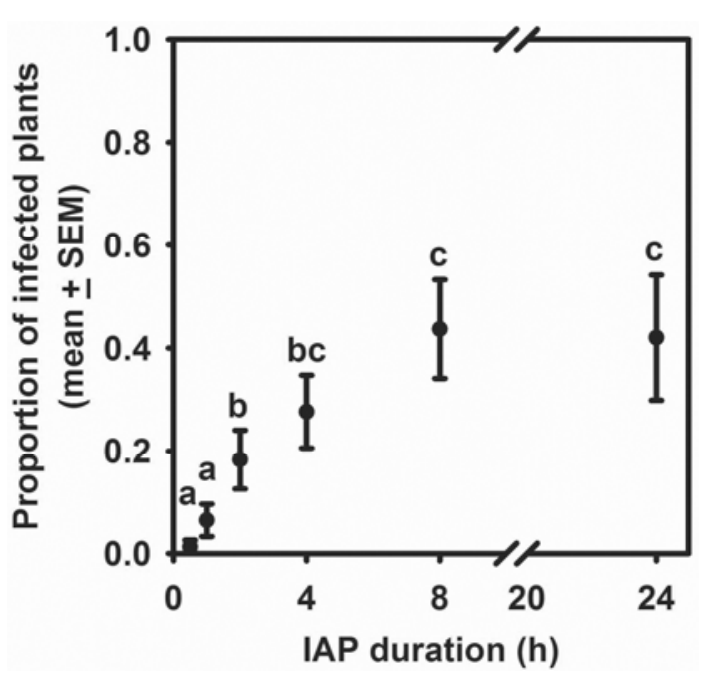

Fig. 4. Frequency of Squash vein yellowing virus (SqVYV) infection of 'Sunray' squash when exposed to cohorts of 30 Bemisia tabaci adults for inoculation access periods (IAPs) of 0.5 to $24 \mathrm{~h}$. B. tabaci adults had been given an acquisition access period of $24 \mathrm{~h}$. Data are the mean proportion ( \pm standard error of the mean [SEM]) of target plants infected with SqVYV. Means with different letters are significantly different $(P<0.05)$.

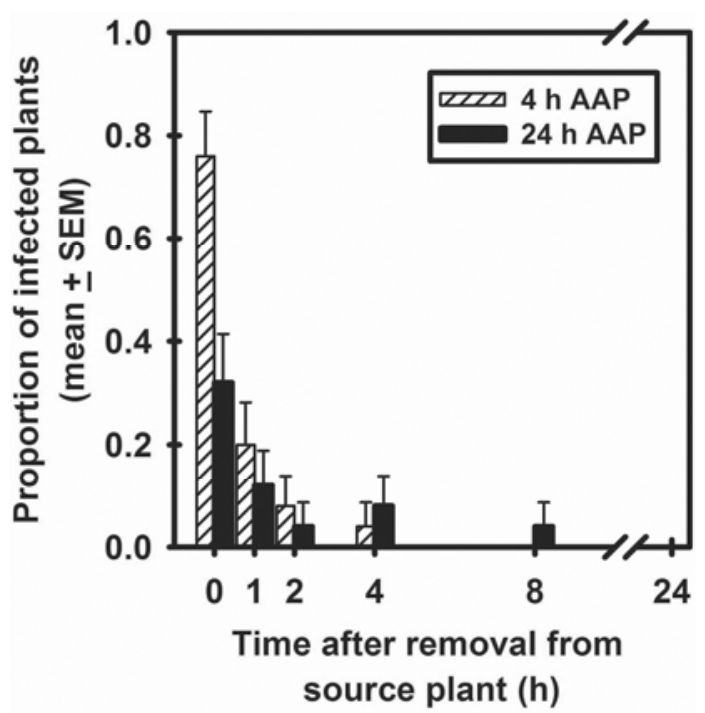

Fig. 5. Effect of time since removal of Bemisia tabaci adults from virus source plants on Squash vein yellowing virus (SqVYV) infection of 'Sunray' squash. $B$. tabaci adults were given either a 4 - or 24 -h acquisition access period (AAP) on SqVYV infected source plants followed by a 0 - to $24-\mathrm{h}$ period of exposure to noninfected plants. After this time period, B. tabaci were transferred to new noninfected Sunray squash for a $24-h$ inoculation access period. Data are mean proportions ( \pm standard error of the mean [SEM]) of infected plants. 
AAP was limited to 1 to $2 \mathrm{~h}$, transmission was only likely to occur with the longer IAP durations (Fig. 6).

\section{Discussion}

Our results demonstrate that Bemisia tabaci transmits SqVYV in a semipersistent manner. By $24 \mathrm{~h}$ after acquisition, whiteflies no longer transmitted virus to target plants. However, acquisition and inoculation periods were considerably longer than the short AAPs and IAPs characteristic of transmission of the nonpersistently transmitted viruses. The AAPs and IAPs likely represent the time it takes for the whitefly to reach the phloem plus the time needed to acquire or to release enough virus particles to cause infection. Efficiency of transmission increased with AAPs up to $4 \mathrm{~h}$ but often declined when the AAP was increased to $24 \mathrm{~h}$. Finally, in transmission of SqVYV, there does not appear to be a true latent period (i.e., a complete cycle of transmission occurs too quickly for a circulative mode of transmission to be operating).

In general, the characteristics of transmission of SqVYV by $B$. tabaci were similar to those reported for CVYV with the same vector $(10,18)$. We found a mean of $22 \%$ transmission when 15 whiteflies per plant were used and a maximum of $57 \%$ when 30 whiteflies per plant were used with a 24-h AAP and a 24-h IAP. In one of the experiments to evaluate different AAPs, a high of $88 \%$ transmission was obtained with 30 whiteflies per plant and an 8-h AAP. Efficiency of transmission when 24-h AAPs and IAPs were used, however, was lower than that reported by Harpaz and Cohen (10) and Mansour and Al-Musa (18) for CVYV. For example, CVYV was transmitted to $42 \%$ of plants with 20 whiteflies per plant (10) and $55 \%$ of plants when 15 to 20 whiteflies per plant were used (18). Further testing is needed to determine whether single whiteflies can transmit SqVYV and if there is a difference between males and females.

An AAP of 20 to 30 min with an IAP of $24 \mathrm{~h}$ was sufficient for transmission of CVYV, with a peak at $4 \mathrm{~h}(10,18)$. Similarly, in our experiments, whiteflies could acquire virus in as little as $30 \mathrm{~min}$, with a peak of transmission at $4 \mathrm{~h}$. In both our experiments and in those of Mansour and Al-Musa (18), transmission declined when the AAP was $24 \mathrm{~h}$ long. We can only speculate that continued feeding somehow interferes with attachment of virus particles or shifts the balance from attachment to release.

In contrast to results reported for CVYV, we found very low transmission with a 30-min IAP (1 infected plant of a total of 75 plants in three replicates) and a 24-h AAP. Harpaz and Cohen (10) found transmission after $10 \mathrm{~min}$ and Mansour and Al-Musa (18) found transmission after $15 \mathrm{~min}$. The longer minimum time for inoculation for SqVYV may be the result of differences in the population of whiteflies used, the host plant, the virus, the conditions of the experiments (e.g., temperature), or some combination of these factors. With SqVYV, maximum transmission occurred with an IAP of $4 \mathrm{~h}$ in one replicate that included time points up to $24 \mathrm{~h}$. This is similar to what was found for CVYV; that is, maximum transmission occurred with either a 1-h IAP (10) or a 4-h IAP (18). In the second replicate of our experiment, however, transmission continued to increase between 4 and $8 \mathrm{~h}$. This suggests that few new infections would occur after this time, with virtually all virus being released after $8 \mathrm{~h}$.

Consistent with the results above, whiteflies did not retain the ability to transmit virus for very long ( $4 \mathrm{~h}$ in one replicate of the experiment and $8 \mathrm{~h}$ in a second), with no transmission by $24 \mathrm{~h}$ after removal from infected plants. Harpaz and Cohen (10) reported retention times between 4 and $6 \mathrm{~h}$, and Mansour and Al Musa (18) found that whiteflies transmitted virus up to $5 \mathrm{~h}$ after feeding on an infected source plant. In contrast, Zouba et al. (31) found a retention time of up to 5 days for Squash yellow leaf curl virus, a whitefly-transmitted poty-like virus that has not been fully characterized.

The minimum time to complete a cycle of transmission was short: a 1-h AAP and a 2-h IAP resulted in transmission of SqVYV to 1 in 20 plants, although consistent transmission required a 4-h AAP and IAP. Times reported for a complete cycle of transmission of CVYV are even shorter. Harpaz and Cohen (10) reported infection after a 30-min AAP and a 30-min IAP, and Mansour and AlMusa (18) reported transmission after a 1-h AAP and a 15-min IAP. Again, it is difficult to know if differences in transmission of SqVYV and CVYV are related to differences in the viruses, whiteflies, host plants, experimental conditions such as temperature, or some combination of these factors. In earlier experiments, in which target plants were placed in large cages with hundreds of whiteflies that had been given a 24-h AAP on SqVYV-infected plants, a 2-h IAP was enough to result in high levels of transmission (1). Under field conditions, with high populations of whiteflies, a complete cycle of transmission may well be shorter than what we have found to date in our laboratory and greenhouse experiments.

It is difficult to compare transmission of SqVYV with closely related CBSV, because studies of CBSV transmission are limited. Although high rates of spread of CBSV under field conditions appear to be related to high populations of whiteflies (B. tabaci), it has been difficult to demonstrate transmission under controlled conditions (19), with only low rates (20 to $22 \%$ ) found when 48-h AAPs and IAPs were used. Maruthi et al. (19) suggested that low virus titer in the source plants and a difference within plants in the distribution of the virus versus the distribution of feeding whiteflies could limit virus acquisition by whiteflies and result in low rates of transmission. The acquisition phase also seems to be a limiting factor for SqVYV transmission, as seen in the results of our minimum cycle time experiment (i.e., inoculation occurs more rapidly than acquisition). In addition, we found that a 24-h AAP resulted in lower transmission than a 4- to 8-h AAP. It is possible that CBSV would be more efficiently transmitted with a shorter AAP.

In conclusion, we have shown that the parameters of transmission of SqVYV are consistent with a semipersistent type of transmission. Further work to determine the site of virus attachment is needed, as is proof that SqVYV does not cross gut membranes, a characteristic of circulative transmission (20). Studies are being planned to elucidate the feeding behavior that results in acquisition and inoculation, using the electrical penetration graph (EPG) technique $(8,12,14)$. Another characteristic of semipersistently transmitted viruses, restriction to the phloem (20), apparently does not hold true for CVYV (16), the closest known relative of SqVYV. Inclusions have been identified in the phloem cells of SqVYVinfected cucurbits (1) although they may not be restricted to these

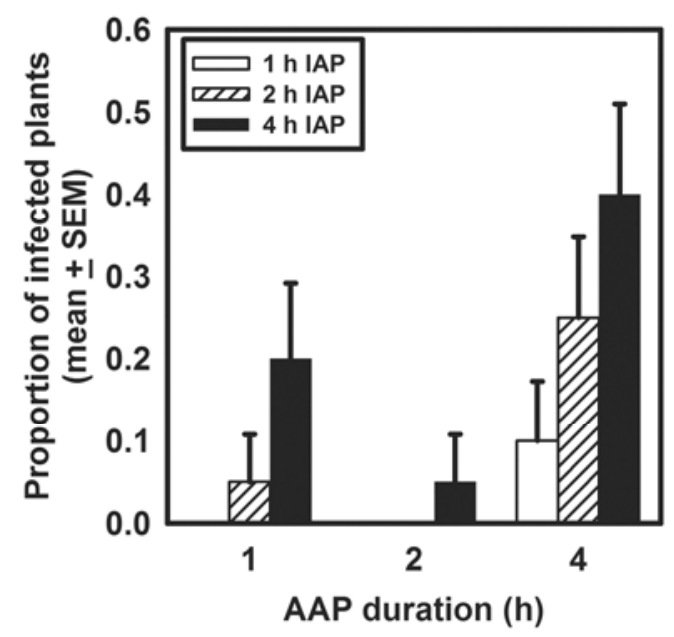

Fig. 6. Joint effects of acquisition access periods (AAPs) and inoculation access periods (IAPs) for cohorts of Bemisia tabaci adults on rates of infection of 'Sunray' squash with Squash vein yellowing virus (SqVYV). Adults of $B$. tabaci were first given AAPs of 1,2 , or $4 \mathrm{~h}$ on infected squash and then transferred in cohorts of 30 to noninfected squash plants for IAPs of 1, 2, or $4 \mathrm{~h}$. Data are the mean proportions ( \pm standard error of the mean [SEM]) of infected plants for each AAP and IAP combination. Transmission was significantly higher with a 4-h AAP than for the 1- or 2-h AAP, which were not significantly different $(P>0.05)$. For the IAP treatments, transmission was significantly different only between the 1- and 4-h $\operatorname{IAP}(P<0.05)$. 
tissues. However, the feeding behavior of whiteflies, according to EPG studies (13), suggests that whiteflies rarely puncture cells until they reach the phloem sieve elements. Thus, whiteflies may only acquire SqVYV (and likely CVYV) from phloem cells regardless of virus distribution in plants. This is in contrast to aphids, which puncture epidermal cells during brief probes, leading to nonpersistent transmission of Potyvirus spp. (24).

Because of the relatively low efficiency of transmission and short retention time of SqVYV coupled with the requirement for several hours of both acquisition and inoculation, it is likely that whitefly populations must be fairly high before epidemics occur in the field. Watermelon vine decline often seems to become widespread just before harvest, perhaps because whitefly populations or inoculum sources have had time to increase during the growing season. Cultural practices such as harvesting that disturb feeding whiteflies may promote virus spread. Watermelon is probably particularly vulnerable because of the large size and low density of plants within the field.

Managing whiteflies has had an impact on the incidence of disease in watermelons in Florida (3). The combination of reflective mulch and insecticides (imidacloprid, applied to the soil at planting, and spiromesifen, applied to foliage) reduced the percentage of watermelon fruit with symptoms of SqVYV by almost half and significantly reduced the season-long area under the disease progress curve (15). Ultimately, interference with transmission, either biochemically or through host plant resistance to the virus or the whitefly, will be needed to effectively control the disease under all conditions. In the meantime, quantifying parameters of transmission will contribute to the development of a decision support system to manage SqVYV.

\section{Acknowledgments}

We thank J. C. Turner, C. Wilkinson, A. Porter, and C. Vanderspool for their excellent technical assistance; and F. Cervantes and C. Webster for valuable discussions.

\section{Literature Cited}

1. Adkins, S., Webb, S. E., Achor, D., Roberts, P. D., and Baker, C. A. 2007. Identification and characterization of a novel whitefly-transmitted member of the family Potyviridae isolated from cucurbits in Florida. Phytopathology 97:145-154.

2. Adkins, S., Webb, S. E., Baker, C. A., and Kousik, C. S. 2008. Squash vein yellowing virus detection using nested polymerase chain reaction demonstrates that the cucurbit weed Momordica charantia is a reservoir host. Plant Dis. 92:1119-1123.

3. Adkins, S., Webster, C. G., Kousik, C. S., Webb, S. E., Roberts, P. D., Stansly, P. A., and Turechek, W. W. 2011. Ecology and management of whitefly-transmitted viruses of vegetable crops in Florida. Virus Res. 159:110-114.

4. Akad, F., Webb, S., Nyoike, T. W., Liburd, O. E., Turechek, W., Adkins, S., and Polston, J. E. 2008. Detection of Cucurbit leaf crumple virus in Florida cucurbits. Plant Dis. 92:648.

5. Blair, M. W., Bassett, M. J., Abouzid, A. M., Hiebert, E., Polston, J. E., McMillan, R. T., Graves, W., and Lamberts, M. 1995. Occurrence of bean golden mosaic virus in Florida. Plant Dis. 79:529-533.

6. Chen, J., McAuslane, H. J., Carle, R. B., and Webb, S. E. 2004. Effects of Bemisia argentifolii (Homoptera: Aleyrodidae) infestation and squash silverleaf disorder on zucchini yield and quality. J. Econ Entomol. 97:20832094.

7. Duffus, J. E. 1996. Whitefly-borne viruses. Pages 255-263 in: Bemisia 1995: Taxonomy, Biology, Damage Control and Management. Intercept, Ltd., Andover, UK

8. Fereres, A., and Collar, J. L. 2001. Analysis of noncirculative transmission by electrical penetration graphs. Pages 87-109 in: Virus-Insect-Plant In- teractions. K. F. Harris, O. P. Smith, and J. E. Duffus, eds. Academic Press, San Diego, CA

9. Gray, S. M., and Banerjee, N. 1999. Mechanisms of arthropod transmission of plant and animal viruses. Microbiol. Mol. Biol. Rev. 63:128-148.

10. Harpaz, I., and Cohen, S. 1965. Semipersistent relationship between cucumber vein yellowing virus (CVYV) and its vector, the tobacco whitefly (Bemisia tabaci Gennadius). Phytopathol. Z. 54:240-248.

11. Huber, M. 2006. Taking vital vines. Citrus Veg. Mag. 70:22-24.

12. Jiang, Y. X., de Blas, C., Barrios, L., and Fereres, A. 2000. Correlation between whitefly (Homoptera: Aleyrodidae) feeding behavior and transmission of tomato yellow leaf curl virus. Ann. Entomol. Soc. Am. 93:573-579.

13. Johnson, D. D., and Walker, G. P. 1999. Intracellular punctures by the adult whitefly Bemisia argentifolii on DC and AC electronic feeding monitors. Entomol. Exp. Appl. 92:257-270.

14. Johnson, D. D., Walker, G. P., and Creamer, R. 2002. Stylet penetration behavior resulting in inoculation of a semipersistently transmitted closterovirus by the whitefly Bemisia argentifolii. Entomol. Exp. Appl. 102:115-123.

15. Kousik, C. S., Adkins, S. T., Turechek, W. W., and Roberts, P. D. 2008. Use of reflective plastic mulch and insecticide sprays to manage viral watermelon vine decline in Florida, 2007. Plant Dis. Manage. Rep. 2:V169.

16. Lecoq, H., Desbiez, C., Delécolle, B., Cohen, S., and Mansour, A. 2000. Cytological and molecular evidence that the whitefly-transmitted Cucumber vein yellowing virus is a tentative member of the family Potyviridae. J. Gen. Virol. 81:2289-2293.

17. Li, W., Hilf, M. E., Webb, S. E., Baker, C. A., and Adkins, S. 2008. Presence of P1b and absence of HC-Pro in Squash vein yellowing virus suggests a general feature of the genus Ipomovirus in the family Potyviridae. Virus Res. 135:213-219.

18. Mansour, A., and Al-Musa, A. 1993. Cucumber vein yellowing virus; host range and virus vector relationships. J. Phytopathol. 137:73-79.

19. Maruthi, M. N., Hillocks, R. J., Mtunda, K., Raya, M. D., Muhanna, M., Kiozia, H., Rekha, A. R., Colvin, J., and Thresh, J. M. 2005. Transmission of Cassava brown streak virus by Bemisia tabaci (Gennadius). J. Phytopathol. 153:302-312.

20. Nault, L. R. 1997. Arthropod transmission of plant viruses: A new synthesis. Ann. Entomol. Soc. Am. 90:521-541.

21. Ng, J. C. K., and Falk, B. W. 2006. Virus-vector interactions mediating nonpersistent and semipersistent transmission of plant viruses. Annu. Rev. Phytopathol. 44:183-212.

22. Polston, J. E., Hladky, L. L., Akad, F., and Wintermantel, W. M. 2008. First report of Cucurbit yellow stunting disorder virus in cucurbits in Florida. Plant Dis. 92:1251.

23. Polston, J. E., McGovern, R. J., and Brown, L. G. 1999. Introduction of tomato yellow leaf curl virus in Florida and implications for the spread of this and other geminiviruses of tomato. Plant Dis. 83:984-988.

24. Powell, G. 1991. Cell membrane punctures during epidermal penetrations by aphids: Consequences for the transmission of two potyviruses. Ann. Appl. Biol. 119:313-321.

25. Roberts, P. D., Muchovej, R., Urs, R., Achor, D., Baker, C., Bruton, B., and Adkins, S. 2005. Investigations into a mature watermelon vine decline and fruit rot. (Abstr.) Phytopathology 95:S89.

26. Schuster, D. J., Mueller, T. F., Kring, J. B., and Price, J. F. 1990. Relationship of the sweetpotato whitefly to a new tomato fruit disorder in Florida. HortScience 25:1618-1620.

27. Turechek, W. W., Kousik, C. S., and Adkins, S. 2010. Distribution of four viruses in single and mixed infections within infected watermelon plants in Florida. Phytopathology 100:1194-1203.

28. Uzest, M., Gargani, D., Drucker, M., Hebrard, E., Garzo, E., Candresse, T. Fereres, A., and Blanc, S. 2007. A protein key to plant virus transmission at the tip of the insect vector stylet. Proc. Natl. Acad. Sci. USA 104:1795917964.

29. Wisler, G. C., Li, R. H., Liu, H.-Y., Lowry, D. S., and Duffus, J. E. 1998 Tomato chlorosis virus: A new whitefly-transmitted, phloem-limited, bipartite closterovirus of tomato. Phytopathology 88:402-409.

30. Yokomi, R. K., Hoelmer, K. A., and Osborne, L. S. 1990. Relationships between the sweetpotato whitefly and the squash silverleaf disorder. Phytopathology 80:895-900.

31. Zouba, A. A., Lopez, M. V., and Anger, H. 1998. Squash yellow leaf curl virus: A new whitefly-transmitted poty-like virus. Plant Dis. 82:475-478. 